Int. J. Electrochem. Sci., 12 (2017) $9882-9895$

\title{
High-temperature Corrosion Investigation of the Inconel-600 in Molten Sulfate/Vanadate Mixtures Using Electrochemical Techniques
}

\author{
N. S. Flores García, C. Cuevas Arteaga* \\ Centro de Investigación en Ingeniería y Ciencias Aplicadas, Universidad Autónoma del Estado de \\ Morelos. Av. Universidad 101. Col. Chamilpa, 62210. Cuernavaca, Mor., México. \\ *E-mail: ccuevas@uaem.mx
}

doi: $10.20964 / 2017.10 .90$

Received: 16 April 2017 / Accepted: 9 June 2017 / Published: 12 September 2017

In this paper, the results obtained from polarization curves (PC) and Electrochemical Impedance Spectroscopy (EIS) for Inconel-600 exposed in two different compositions of corrosive molten salts are presented. The Inconel-600 samples were exposed to high sulfate $\left(80 \mathrm{~mol} \% \mathrm{Na}_{2} \mathrm{SO}_{4}-20 \mathrm{~mol} \%\right.$ $\left.\mathrm{V}_{2} \mathrm{O}_{5}\right)$ and high vanadium $\left(80 \mathrm{~mol} \% \mathrm{~V}_{2} \mathrm{O}_{5}-20 \mathrm{~mol} \% \mathrm{Na}_{2} \mathrm{SO}_{4}\right)$ molten salts at $700{ }^{\circ} \mathrm{C}$ during $120 \mathrm{~h}$. Tafel slopes, current densities and corrosion potentials were obtained from polarization curves for both corrosive systems. EIS was used to determine the controlling corrosion mechanism, either charge transfer (activation) or mass diffusion, and the charge transfer resistance Rct. Scanning electron microscopy analysis (images and mappings) showed that Inconel-600 exposed to the high sulfate molten salt suffered inter-granular corrosion, which was due to an oxidation process through the grain boundaries, just below the metal-scale interface; whereas exposed to the high vanadium molten salt, Inconel-600 corroded by means of a generalized corrosion process, which was due to the diffusion of sulfur to the surface and inside the alloy. The corrosion mechanisms suffered by the Inconel-600 in both corrosive molten salts were supported by X-ray diffraction analyses of the corrosion products, which showed the presence of chromium, iron and nickel oxides together with some vanadates as secondary compounds.

Keywords: Superalloy, molten salts, hot corrosion, EIS.

\section{$\underline{\text { FULL TEXT }}$}

(C) 2017 The Authors. Published by ESG (www.electrochemsci.org). This article is an open access article distributed under the terms and conditions of the Creative Commons Attribution license (http://creativecommons.org/licenses/by/4.0/). 